\title{
金ナノ粒子に着目したドラッグデリバリー技術・ナノメディスンの開発
}

\author{
尾 関哲也, ${ }^{*}$ 田上辰 秋
}

\section{Development of Drug Delivery Technology and Nanomedicine by Using Gold Nanoparticles}

\author{
Tetsuya Ozeki* and Tatsuaki Tagami \\ Graduate School of Pharmaceutical Sciences, Nagoya City University; 3-1 Tanabe-dori, Mizuho-ku, Nagoya 467-8603, Japan.
}

(Received August 20, 2020)

\begin{abstract}
Nanomedicine is a new medical field involving the use of nanoparticles. Early examples of biocompatible nanomedicines include liposomes (Doxil ${ }^{\circledR}$ ) and albumin nanoparticles (Abraxane ${ }^{\circledR}$ ), and promising new nanomedicines include nanocarriers such as nanomicelles and nanoemulsions. A new trend towards the use of metal-based nanoparticles, including gold nanoparticles, has led to global clinical trials. These particles exhibit novel properties compared to conventional nanomedicines such as liposomes and albumin nanoparticles. These properties hold promise for nanomedicines, and thus the biodistribution and pharmacokinetics of metal-based nanoparticles should be carefully investigated. This had led to an increasing number of clinical trials investigating metal nanoparticles and inorganic nanoparticles. The present review evaluates multi-functional gold nanoparticles described in recent articles and shows that the unique properties of gold nanoparticles are applicable for not only drug delivery, but also for imaging. The combined therapeutic modality between therapeutics and diagnostics is called "theranostics" and is promising for future personalized cancer therapy. This review also introduces recent research from our laboratory involving the use of various kinds of molecules [polyethylene glycol (PEG), drug/cyclodextrin inclusion complexes, biosimilars and small interfering (siRNAs) ] loaded onto and/or conjugated with gold nanoparticles.
\end{abstract}

Key words_ _ gold nanoparticle; theranostics; drug delivery; imaging

\section{1. はじめに}

ナノメディシン（ナノ医薬品とも呼ばれる）は, ナノテクノロジーを医薬品に適用させたものであ り，これまでに様々なドラッグナノキャリアが開発 されてきた. 代表的なナノメディシンとしてドキシ ルやアブラキサンが知られている. ドキシルは, 抗 がん剂であるドキソルビシンをリン脂質ナノカプセ ルである $100 \mathrm{~nm}$ 程度のリポソームに含有させたも のであり，リポソーム表面には，ポリエチレングリ コールが化学修飾されている。 ドキシルは，がん組 織内に受動的に蓄積する効果 (enhanced permeability and retention effect, EPR 効果と呼ばれる) がよ く知られている. またアブラキサンは, アルブミン に抗がん剂であるパクシタキセルが結合した $100 \mathrm{~nm}$ 程度のナノ粒子であり，パクリタキセルの

名古屋市立大学大学院薬学研究科（T467-8603 名古屋 市瑞穂区田辺通 3-1)

*e-mail: ozekit@phar.nagoya-cu.ac.jp

本総説は, 日本薬学会第 140 年会シンポジウム S40 で

発表した内容を中心に記述したものである.
難水溶性の問題を解決した製剤として知られてい る.いずれの製剤も生体親和性の高い材料が薬物の ナノキャリアとして使用されており，安全面をクリ アしている.

現在行われているナノメディシンの臨床試験のほ とんどは，これらの生体親和性の高いリポソームや アルブミンナノ粒子に関するものであるが，最近新 しい傾向がみられている. ${ }^{1-3)}$ その 1 つとして，金 を含む金属やシリカなどの無機物を含んだナノ粒子 に関する臨床試験が行われている。これらのナノ粒 子に関しては, 生体内の体内動態や代謝・排泄の課 題があるので適用する疾患について安全性を注意深 く検討する必要があるものの，その一方で，これま での生体親和性のよいナノ粒子にはみられない有用 な異なる性質を数多く有していることから，新しい ナノメディシンとして期待されている.

筆者の研究室は, 名古屋市立大学と名古屋工業大 学の連携大学院（共同ナノメディシン専攻）の基幹 研究室の 1 つであり, 全国でも稀な薬学と工学との 融合を目指した，ナノメディシンを含む製剤に関す 


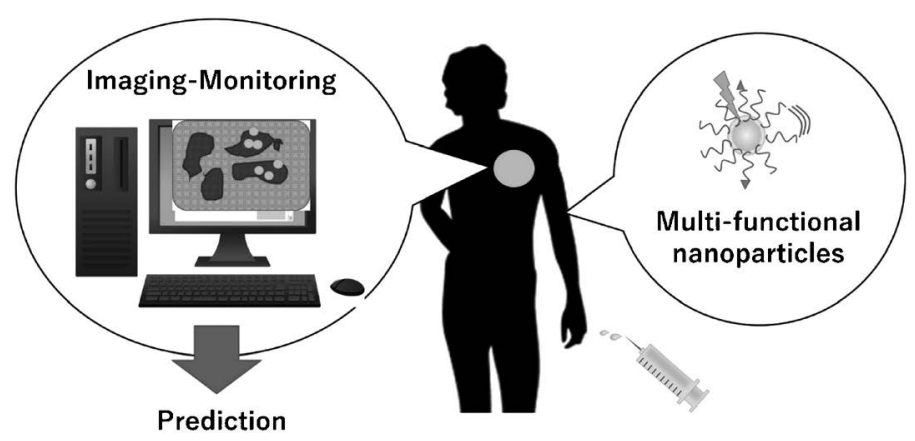

Fig. 1. Cancer Nanotheranostics

る研究を行ってきた，本稿では，金を素材としたナ ノメディシンに関する研究について概説し, 当研究 室が行つてきた研究内容についても少し紹介を行う.

2. 金ナノ粒子をベースとしたドラッグデリバ リー・イメージング研究とセラノスティクス

金を用いることの利点として，大きくわけて $2 つ$ の性質が知られている，1つは，フォトサーマル効 果である．金の形状を変化させることにより，光の 吸収波長帯を変化させることができるため，特定の 波長の光を吸収し，金ナノ粒子が加熱され，加熱に よりがんの温熱療法などに用いられている。また温 度の上昇に伴い, 別の温熱感受性ナノ粒子から薬物 を放出させるような面白い仕組みが試みられてい る.もう 1 つはイメージングへの応用である，これ も光の吸収波長帯を変化させることで特定の蛍光を 発する粒子が作製されている．到達した粒子の量を モニターすることにより治療効果の程度を予測する ような研究も行われている，治療と診断を組み合わ せた治療様式はセラノスティクス（Theranostics, Therapeutics と Diagnostics の造語）と呼ばれ，ド ラッグデリバリーとイメージングをつなぐ新しい研 究領域としてこれまでに活発な研究が行われてきた (Fig. 1)。医療機器やイメージング機器を用いて多 機能性ナノ粒子が各組織（Fig. 1 ではがんを例）に 集積し, 薬物送達効率をイメージング，モニタリン グすることで，その後の治療効果や予後を予測する 画期的な方法である，がんについては，個人差が大 きく同じ機能性ナノ粒子を投与したとしても集積す るナノ粒子の量は個人によって大きく異なる。この ため集積した量を知ることにより，次の治療におけ る，善後策を考えることができる，セラノスティク スは，がんの個別化医療において重要な治療様式で あると考えられている.

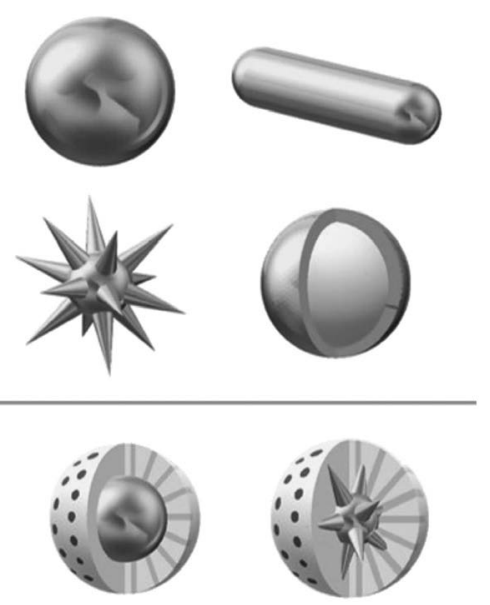

Fig. 2. Functional Gold Nanoparticles

本項目では，筆者が面白いと感じた金ナノ粒子を ベースとした近年の研究について少し紹介する (Fig. 2)。Fales らは，粒子の表面が突起している 金ナノスターを調製している. ${ }^{4)} こ の$ 粒子は，一重 合酸素を出す光線力学療法と表面増強ラマン散乱を 可能にする．またこの金ナノスターには，シリカが 被覆されており，漫画の「ドラゴンボール」のよう な形状をしている，筆者の研究室も金ナノスターを 作製したものを研究しているが，金ナノスターの突 起物が不安定であり，環境変化でくずれるケースも あることから，シリカで被覆する処理は，金ナノス

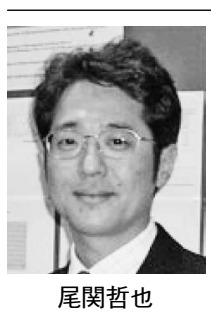

名古屋市立大学大学院薬学研究科教 授。名市大一名工大 共同大学院「共同 ナノメディシン科学専攻」教授 (兼務). 日本薬剤学会副会長 $(2020$ 年 ), 製 剂機械技術学会理事 (2017 年 ), 創 剤フォーラム代表世話人 (2019 年〜),

FIP Congress 及 び PSWC Program Committee Member (2018〜), 日本薬 剂学会タケル\&アヤ・ヒグチ記念賞 (第 15 回）（2019 年）. 
ターの性質を保持する方法として有用ではないかと 考えている.

Montoto らのグループは, 金ナノスターにメソ ポーラスシリカを被覆した機能性粒子の作製を行つ

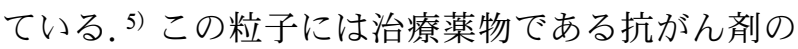
ドキソルビシンを吸着させており，レーザーを照射 して加温することにより, 内部のドキソルビシンが 放出されるしくみになっている.

Wang らは，メソポーラスなナノフレイムワーク

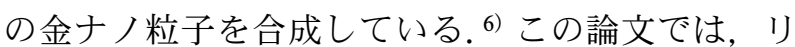
ン脂質ナノカプセルであるリポソームをテンプレー トとしてフレイムワークを合成していることが特徴 である．この粒子は, 光温熱効果だけでなく, 光音 響イメージングにも使用可能であり，担がんマウス への顕著な蓄積とレーザー照射による抗がん効果を 認めている.

3. 当研究室で行ってきた金をべースとしたナノ メディシンに関する研究

当研究室における金ナノ粒子をべースとしたナノ メディシンの開発当初の研究としては，人工善玉コ レステロール (high density lipoprotein; HDL) を模 した機能性粒子の開発が挙げられる，金ナノ粒子を 核とし，粒子両面には，アポリポタンパクと脂質メ ディエーターとして知られているスフィンゴシン 1 リン酸を搭載した粒子の作製を行つた．粒子の大き さは，生体内の HDL とほぼ同等の $20 \mathrm{~nm}$ ほどの大 きさの粒子が得られた。 またこの人工 HDL 粒子は, in vitro, in vivo において顕著な抗炎症効果を示した.

次に筆者のグループは，金ナノ粒子の表面に環状 オリゴ糖であるシクロデキストリンを結合させた機 能性金ナノ粒子を作製した. ${ }^{7)}$ シクロデキストリン は疎水性領域を持ち内部に薬物の疎水部位を包接す ることができることから, 難水溶性薬物の可溶化の 手段として広く用いられてきた．結合するシクロデ キストリンの種類（ $\alpha, \beta, \gamma)$ を変更することによ り, 包接する薬物を変えることができる，本研究で は，難水溶性化合物であるクルクミンを包接したシ クロデキストリンを金ナノ粒子表面に結合した機能 性ナノ粒子を調製し，難水溶性化合物を搭載したナ ノ粒子のモデルを作製した。合成したクルクミン包 接シクロデキストリン結合金ナノ粒子（curcuminloaded cyclodextrin-conjugated gold nanoparticles; cur-CD-GNPs）は， $30 \mathrm{~nm}$ 程度の大きさであり，
ヒト肺がん細胞株に顕著な取り込みを示し，エンド サイトーシス経路で取り込まれていることが示唆さ れている。 また cur-CD-GNPs は，このがん細胞株 に対し顕著な殺細胞効果を示した。当研究室はクル クミンを用いて，これまでにスプレードライ法を用 いたクルクミンナノコンポジット粒子（マイクロ粒 子の中にクルクミンナノ粒子を含有させたもの）の 調製や, ${ }^{8)}$ 生分解性ポリマーであるポリ乳酸・グリ コール酸共重合体（poly lactic-co-glycolic acid; PLGA）の中にクルクミンを含有させた粒子, ${ }^{9}$ 抗 酸化作用のある不飽和脂肪酸リン脂質誘導体にクル クミンを含有させたナノ粒子, ${ }^{10)}$ 産業用超短パルス レーザー（フェムト秒レーザー）により一部をナノ レベルまで粉砕したクルクミン粒子の調製11)など, クルクミンの難水溶性を克服するための研究を行つ てきている.

また，金ナノ粒子に抗体医薬品であるラニビズマ ブとポリエチレングリコールを結合した機能性ナノ 粒子についても作製を行つた. ${ }^{12)}$ ラニビズマブは, 加齢黄斑変性症の治療薬として使用されている抗体 医薬品として知られており，効果的な VEGF 阻害 薬として知られている. しかしながら月 1 回の眼内 投与を必要とするため, 患者のみならず医療スタッ フにとって負担の大きな治療である。 またラニビズ マブは抗体断片（Fab 断片）であることから，通常 の Fc 部位を持つ抗体医薬と比較して分子量が小さ く, 眼内滞留性の面で劣る可能性がある.このため 筆者は，ラニビズマブを眼内でより長期間滞留させ る工夫を行ってきた，以前の基礎的検討では，生分 解性ポリマーである PLGA を用いてラニビズマブ を封入したPLGA マイクロ粒子を作製し，ラニビ

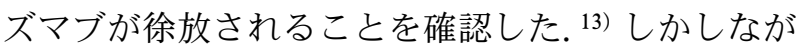
ら，マイクロ粒子を眼内に分散させることには問題 があるため, 本研究では, 極小の金ナノ粒子にラニ ビズマブを結合し，粒子の分散性を高めるためにポ リエチレングリコールを金ナノ粒子に表面修飾した ナノ粒子の作製を新たに行った。合成したラニビズ マブ・ポリエチレングリコール結合金ナノ粒子は, だいたい $30 \mathrm{~nm}$ 程度の大きさであり，ポリエチレ

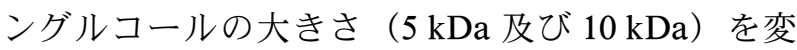
えたものと比較したが，ほぼ同等の性質を示した. また，ヒ卜臍帯静脈内皮細胞 (human umbilical vein endothelial cell; HUVEC) と細胞外基質タンパ 
ク質を多く含む Matrigel ${ }^{\circledR}$ 用いた実験系により， 新生血管阻害作用の評価を行ったところ，この粒子 は顕著な阻害作用を示し，優れた機能性粒子である ことが示唆されている. 今回使用したラニビズマブ はバイオシミラー（バイオ医薬品後続品）であるこ とから，バイオシミラーを使用した，従来品よりも もつと優れた性質を持つ新たなバイオ医薬品として 今後が期待できる.

一方で，機能性核酸である small interfering RNA（siRNA）にスペーサーを入れ，塩化金酸溶 液中で還元することでワンステップで， siRNA が 表面に配位した金ナノ粒子を作製することができる ことを報告した。 ${ }^{14)}$ siRNA は，配列特異的な遺伝子 サイレンシング効果を示す化合物として知られてい るが，以前の検討で，配列非特異的に血管新生を抑 制する効果が報告されている。今回作製した siRNA が搭載された金ナノ粒子においても，その 遺伝子配列に特異的な siRNA を設計することで遺 伝子サイレンシング効果を確認した一方で，上述の

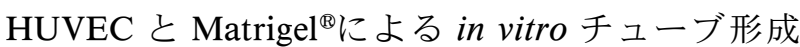
能の評価において，配列の有無にかかわらずこの siRNA 搭載金ナノ粒子において，血管新生抑制効 果を確認している。この siRNA 搭載金ナノ粒子に ついて，眼内の血管新生に対して有効な，金をべー スとしたナノメディシンとして有効ではないかと考 えられる。

\section{4. おわりに}

金をキャリアとした様々な機能性ナノ粒子につい て, 当研究室の内容も含めて解説を行った. 従来の ナノメディシンにはない有用な性質を持っているこ とから，金ナノ粒子や他の金属ナノ粒子，無機ナノ 粒子も含めて, 次世代のナノメディシンとして有望 視されている，その一方で，冒頭でも少しふれたよ うに，これらの粒子は，生体内にはない異物として の要素があるため, 体内動態や副作用の点について リスクベネフィットの観点で精査していく必要があ ると言える. 臨床試験も含めて, 今後の研究の進展 が期待される。

謝辞＼cjkstart本稿の作成にあたり，作図でご協力頂き ました，井上智貴様に感謝申し上げます。 利益相反＼cjkstart開示すべき利益相反はない.

\section{REFERENCES}

1) Tagami T., Ozeki T., J. Pharm. Sci., 106, 2219-2226 (2017).

2) Tagami T., Ozeki T., “Drug Delivery System - Recent Progress of Tissue, Intracellular and Intranuclear Delivery Technology for Biophamaceutical Development-, Update and trend of clinical trials about nanomedicine," CMC Publishing Co., Ltd., Tokyo, 2018, pp.21-32.

3) Tagami T., Ozeki T., Organ Biology, 24, 5460 (2017).

4) Fales A. M., Hsiangkuo Yuan H., Vo-Dinh T., Langmuir, 27, 12186-12190 (2011) .

5) Montoto A. H., Montes R., Samadi A., Gorbe M., Terrés J. M., Cao-Milán R., Aznar E., Ibañez J., Masot R., Marcos M. D., Orzáez M., Sancenón F., Oddershede L. B., Martínez-Máñez R., ACS Appl. Mater. Interfaces, 10, 27644-27656 (2018).

6) Wang J., Sun J., Wang Y., Chou Y., Zhang Q., Zhang B., Ren L., Wang H., Adv. Funct. Mater., 30, 1908825 (2020).

7) Hoshikawa A., Nagira M., Tane M., Fukushige K., Tagami T., Ozeki T., Biol. Pharm. Bull., 41, 908-914 (2018).

8) Taki M., Tagami T., Fukushige K., Ozeki T., Int. J. Pharm., 11, 104-110 (2016) .

9) Morikawa Y., Tagami T., Hoshikawa A., Ozeki T., Biol. Pharm. Bull., 41, 899-907 (2018).

10) Ibrahim S., Tagami T., Kishi T., Ozeki T., Int. J. Pharm., 540, 40-49 (2018).

11) Tagami T., Imao Y., Ito S., Nakada A., Ozeki T., Int. J. Pharm., 468, 91-96 (2014) .

12) Hoshikawa A., Tagami T., Morimura C., Fukushige K., Ozeki T., J. Drug Deliv. Sci. Technol., 38, 45-50 (2017).

13) Tanetsugu Y., Tagami T., Terukina T., Ogawa T., Ohta M., Ozeki T., Biol. Pharm. Bull., 40, 145-150 (2017).

14) Takeuchi T., Tagami T., Fukushige K., Ozeki T., J. Drug Deliv. Sci. Technol., 47, 411-416 (2018) 